\title{
The Role of Enterprise Intelligence through Social Media Support on SMEs' Performance in Increasing Sales
}

\author{
Doni Sahputra $^{1}$, Ade Parlaungan Nasution², Siti Lam'ah Nasution ${ }^{3}$ \\ ${ }_{1,2,3}$ Universitas Labuhanbatu, Indonesia \\ sahputradoni714@gmail.com
}

\begin{abstract}
This study aims to analyze the effect of entrepreneurial intelligence through the role of social media on the performance of SMEs in increasing sales. The type of research used is explanatory research with Accidental Sampling technique. The number of samples determined was 80 respondents. Data analysis in this study using SmartPLS version 3.0 software. The results showed that entrepreneurial intelligence consisting of elements of financial intelligence, emotional intelligence, social intelligence and spiritual intelligence had an effect on the performance of SMEs through the role of social media, social media had an effect on performance and sales and performance had an effect on sales.
\end{abstract}

\section{Keywords}

Entrepreneurial intelligence; social media; performance; sales

\section{Introduction}

The development of business in the SME sector has made business people aware of the importance of marketing strategies in order to continue to be one of the reckless business competitors. The business success can be seen from firm's performance (Pranowo et al., 2020). The marketing strategy is aimed at generating consumer loyalty, starting with the interest in repurchasing the products offered by business actors. In addition to a good marketing strategy, every business actor is expected to be able to understand consumer behavior such as knowing what is needed and what consumers want. Once we understand consumer behavior, the goal of business owners to be able to achieve the maximum possible level of sales and profit will be easy to achieve.

Every business actor hopes that the business they are doing is able to develop and experience significant progress. Therefore, every business owner is required to have entrepreneurial intelligence. According to Santoso et al., (2017: 76) entrepreneurial intelligence is a way that an entrepreneur uses to manage a business both in the present and in the future through financial, emotional, social and spiritual. In addition, entrepreneurial intelligence is not only a skill used to manage a business but can increase the creativity and innovation of the business owner concerned.

The performance achieved in accordance with the objectives set becomes a result of activities human resources that exist in the company and together bring the final result which is based on the level of quality and standards that have been set (Syamsuri \& Siregar, 2018). Siregar et al., (2020) cited that performance related to the firm's profitability. Another factor that can be a trigger in improving the performance of SMEs and the percentage of sales is the role of technological sophistication. It is undeniable that social media contributes so many positive impacts for every business actor. This is because social media is a tool that can be used for promotional activities so that it can expedite the business being undertaken. According to Caleb T. Carr and Rebecca A. Hayes "social media is an internet-based media that allows every user to have the opportunity to interact 
either directly or indirectly, with a wide audience that encourages the value of usergenerated content as well as the perception of interactions with others."

The research carried out has in common with research fromSantoso et al. (2017) with the results of research that financial intelligence, emotional intelligence, social intelligence, and spiritual intelligence together affect the performance of IKM Surabaya City. Balik et al. (2018)with the results of research on spiritual intelligence and emotional intelligence proved to have a positive and significant direct effect on managerial skills and performance of Christian entrepreneurial SMEs in Ambon City. Managerial representation has a positive and significant effect on the performance of Christian entrepreneurial SMEs in Ambon City.

Ludin et al. (2018) partially, intellectual and emotional intelligence have no significant effect on the performance of Muslim entrepreneurs. Both simultaneously show that intellectual intelligence, emotional intelligence, and spiritual intelligence have a significant influence on the performance of Muslim entrepreneurs. Further research fromPurwantini \& Anisa (2018). From the research conducted, it is evident that the role of social media is able to have an impact in the form of benefits on the performance of SMEs which include performance on customer service, sales, marketing, and internal operations. The purpose of this research is to determine the effect of entrepreneurial intelligence and the role of social media in improving the performance of SMEs and their impact on sales. The current use of technology has increased (Siregar et al., 2019).

The benefits of doing this research are to find out what the elements of entrepreneurial intelligence are, how the influence of social media in the business world, what is the performance of SMEs and how to increase sales. Based on a brief explanation and support from previous research that can be used as research support, the title in the study is "The Role of Entrepreneurial Intelligence through Social Media Support on SME Performance in Increasing Sales"

\section{Review of Literature}

\subsection{Entrepreneurial Intelligence}

Entrepreneurial intelligence is in the form of a mindset that produces creativity and innovation with the aim of being able to provide more value from every resource owned by UKM owners. According to research there are four intelligences that will support how an entrepreneur manages his business in order to have high performance. This intelligence includes financial intelligence, emotional intelligence, social intelligence and spiritual intelligence.

\subsection{Financial Intelligence}

Supriyono inside Santoso et al. (2017)states that financial intelligence is the ability a person has that can be used to manage resources both inside and outside the individual who can generate money. Financial intelligence is aimed at achieving financial freedom, which is one of the elements to be achieved in financial well-being. Thus, every business actor is required to have financial intelligence so that it can stabilize the business conditions that are being carried out.

\subsection{Emotional Intelligence}

Emotional intelligence or emotional intelligence refers to how a person manages feelings, both feelings for himself or for others, such as the ability to motivate himself or the ability to be able to control emotions well. Emotional intelligence is needed in dealing 
with various kinds of emotions, including in the work environment. This is because emotions will affect one's performance.

\subsection{Social Intelligence}

Social intelligence, or in other words, is called interpersonal intelligence, which is the skill to understand, interact or develop good relationships with other people. Albrecht defines social intelligence as the ability of an individual to get along well and invite others to work together.

\subsection{Spiritual Intelligence}

Spiritual intelligence is a form of intelligence related to wisdom outside the ego or self / soul consciousness (Inner ZoharYuni Rukhayatun, 2018). Amram and Dryer explain that spiritual intelligence is the ability to apply and cultivate spiritual resources and quality in expanding everyday functions and prosperity.

\subsection{Social media}

Social media is a media that allows interaction between one individual and another that can be done anywhere and does not care about distance or time. Social media is used as an effective choice by business actors when promoting products or services in addition to its minimal cost and global coverage so that it can be accessed by anyone.

\subsection{Performance}

Prawirosentono inside Yuni Rukhayatun (2018), expressing performance is a work result that can be achieved by a person or group of people in an organization, in accordance with their respective authorities and responsibilities, in order to achieve the goals of the organization concerned legally, does not violate the law, and is in accordance with morals and ethics. According to Miner, performance is how someone is expected to function and behave in accordance with the task that has been assigned to him.

\subsection{Sales}

Sales can be interpreted as science and art that affect personalities carried out by sales to invite others to buy the goods or services offered (Swastha in Segati (2018). According to Rangkuti, sales are achievements expressed quantitatively in terms of physical or volume or units of a product. According to Marbun, sales are the total goods or products sold by the company within a certain period of time (Marbun in Segati (2018).

\section{Research Methods}

This type of research is explanatory research. Explanatory research is research that has the nature to provide an explanation for a phenomenon and aims to test theories or hypotheses, where the results of the research will prove the truth of the theory or hypothesis used by the author in the research conducted.(Mauludi, 2018). The population in this study were the owners of UKM who opened their business in the Rantauprapat area. The sampling technique used in this research is Accidental Sampling, which is part of nonprobability sampling. The number of samples specified in the study were 100 respondents. Data collection in this study was carried out through distributing questionnaires given to UKM owners. The data analysis method in this study was carried out with the help of SmartPLS 3.0 software, through two stages of measurement, namely: the Measurement Model (Outer Model) and the Structural Model (Inner Model). 


\section{Result and Discussion}

4.1 Results of Measurement Model Testing

a) Convergent Validity

Table 1. Outer Loading

\begin{tabular}{|c|c|c|}
\hline \multirow{2}{*}{ Financial } & $\mathrm{X} 1.1$ & 0.856 \\
\cline { 2 - 3 } Intelligence & $\mathrm{X} 1.2$ & 0.844 \\
\cline { 2 - 3 } X1) & $\mathrm{X} 1.3$ & 0.759 \\
\hline \multirow{2}{*}{$\begin{array}{c}\text { Emotional } \\
\text { Intelligence } \\
(\mathrm{X} 2)\end{array}$} & $\mathrm{X} 2.1$ & 0.882 \\
\cline { 2 - 3 } & $\mathrm{X} 2.2$ & 0.803 \\
\cline { 2 - 3 } & $\mathrm{X} 2.3$ & 0.727 \\
\hline Social & $\mathrm{X} 2.4$ & 0.726 \\
\cline { 2 - 3 } Intelligence & $\mathrm{X} 3.2$ & 0.942 \\
\cline { 2 - 3 }$(\mathrm{X} 3)$ & $\mathrm{X} 3.3$ & 0.940 \\
\hline \multirow{2}{*}{$\begin{array}{c}\text { Spiritual } \\
\text { Intelligence } \\
(\mathrm{X} 4)\end{array}$} & $\mathrm{X} 4.1$ & 0.873 \\
\cline { 2 - 3 } & $\mathrm{X} 4.2$ & 0.799 \\
\hline \multirow{2}{*}{$\begin{array}{c}\text { Social Media } \\
(\mathrm{Z} 1)\end{array}$} & $\mathrm{Z} 1.3$ & 0.760 \\
\cline { 2 - 3 } & $\mathrm{Z} 1.2$ & 0.894 \\
\cline { 2 - 3 } & $\mathrm{Z} 1.3$ & 0.874 \\
\hline SME & $\mathrm{Y} 1.1$ & 0.807 \\
\cline { 2 - 3 } Performanc & $\mathrm{Y} 1.2$ & 0.886 \\
\cline { 2 - 3 } e (Y1) & $\mathrm{Y} 1.3$ & 0.793 \\
\hline \multirow{3}{*}{ Sales (Y2) } & $\mathrm{Y} 2.1$ & 0.882 \\
\cline { 2 - 3 } & $\mathrm{Y} 2.2$ & 0.832 \\
\cline { 2 - 3 } & $\mathrm{Y} 2.3$ & 0.767 \\
\hline \multirow{2}{*}{ Source: Smart }
\end{tabular}

Source: SmartPLS Processing, 2021

From the table above, it can be seen that each indicator of the research variable has an outer loading value of $>0.7$. Thus, all indicators can be said to be feasible or valid for use in further research and analysis.

b) Discriminant Validity

Table 2. Average variant Extracted

\begin{tabular}{|c|c|}
\hline Variable & AVE \\
\hline Financial Intelligence & 0.836 \\
\hline Emotional Intelligence & 0.738 \\
\hline Social Intelligence & 0.736 \\
\hline Spiritual Intelligence & 0.686 \\
\hline Social media & 0.673 \\
\hline SME performance & 0.660 \\
\hline Sales & 0.620 \\
\hline
\end{tabular}

Source: SmartPLS Processing, 2021 
The above table provides information that each research variable has an AVE value > 0.5 . So it can be concluded that each indicator used has good discriminant validity in compiling its respective variables

c) Reliability

Composite Reliability

Table 3. Composite Reliability

\begin{tabular}{|c|c|}
\hline Variable & Composite Reliability \\
\hline Financial Intelligence & 0.938 \\
\hline Emotional Intelligence & 0.894 \\
\hline Social Intelligence & 0.893 \\
\hline Spiritual Intelligence & 0.868 \\
\hline Social media & 0.866 \\
\hline SME performance & 0.861 \\
\hline Sales & 0.853 \\
\hline
\end{tabular}

Source: SmartPLS Processing, 2021

Based on the table, information is obtained that the value of the composite reliability for each variable is $>0.7$, which means that it fulfills the predetermined composite reliability criteria and it can be concluded that all of these variables have high reliability.

Cronbach Alpha

Table 4. Cronbach Alpha

\begin{tabular}{|c|c|}
\hline Variable & Cronbach Alpha \\
\hline Financial Intelligence & 0.901 \\
\hline Emotional Intelligence & 0.821 \\
\hline Social Intelligence & 0.819 \\
\hline Spiritual Intelligence & 0.794 \\
\hline Social media & 0.770 \\
\hline SME performance & 0.759 \\
\hline Sales & 0.741 \\
\hline
\end{tabular}

Source: SmartPLS Processing, 2021

Based on the data presented in table 4 and the bar chart, we can see that each variable has a Cronbach alpha value $<0.7$. This shows that these variables can be relied on to measure the performance of SMEs and sales.

1) Structural Model Testing Results

In assessing the structural model through the help of the SamrtPLS 3.0 software, it begins by looking at the $\mathrm{R}$-square value for each dependent variable. The $\mathrm{R}$-square value that has been determined in this study is $>0.5$.

Table 5. R-square

\begin{tabular}{|c|c|}
\hline Variable & $\boldsymbol{R}$-square \\
\hline Social media & 0.590 \\
\hline SME performance & 0.651 \\
\hline Sales & 0.545 \\
\hline
\end{tabular}

Source: SmartPLS Processing, 2021 
Based on the table, it can be seen that the R-square value for each research variable. These results indicate that as much as $59 \%$ of social media variables can be explained by independent variables (financial intelligence, emotional intelligence, spiritual intelligence and social intelligence). Henceforth, the SME performance variable can be explained by the Social Media variable of $65.1 \%$. Furthermore, the Sales variable can be explained by the SME performance variable as much as $54.5 \%$.

Furthermore, the research model needs to be assessed for its goodness of fit through the value of the Q-square with the Q-square value obtained>0. The following is a calculation of the Q-square value:

$$
\begin{aligned}
\text { Q-square } & =1-[(1-\mathrm{R} 21) \times(1-\mathrm{R} 22) \times(1-\mathrm{R} 23)] \\
& =1-[(0.41) \times(0.349) \times(0.455)] \\
& =0.935
\end{aligned}
$$

From the results of the above calculations, the Q-square value is obtained of 0.935 , which means that the amount of diversity in the research data that can be proven by the model is $93.5 \%$ while the remaining $6.5 \%$ is explained by other factors not used in this study. Therefore, this research model can be categorized as research with a good goodness of fit.

\subsection{Hypothesis Test Results}

Hypothesis testing is done by looking at the T-Statistics value and the value of the PValues. The hypothesis can be accepted if the T-Statistics value> T-table or T-Statistics> 1.992 and the P-Values value $<0.05$.

Table 6. Hypothesis Testing Results

\begin{tabular}{|l|c|c|c|}
\hline \multicolumn{1}{|c|}{ Correlation } & T-Statistics & P-Values & Ket \\
\hline Financial Intelligence $\rightarrow$ Social Media & 1,986 & 0.048 & Sig. \\
\hline Emotional Intelligence $\rightarrow$ Social Media & 3,149 & 0,000 & Sig \\
\hline Social Intelligence $\rightarrow$ Social Media & 3,431 & 0.001 & Sig \\
\hline Spiritual Intelligence $\rightarrow$ Social Media & 3,628 & 0,000 & Sig \\
\hline Financial Intelligence $\rightarrow$ SME performance & 4,108 & 0,000 & Sig \\
\hline Emotional Intelligence $\rightarrow$ SME Performance & 3,472 & 0,000 & Sig \\
\hline Social Intelligence $\rightarrow$ SME performance & 2,035 & 0.042 & Sig \\
\hline Spiritual Intelligence $\rightarrow$ UKM Performance & 2,042 & 0.042 & Sig \\
\hline Financial Intelligence $\rightarrow$ Social Media $\rightarrow$ SME Performance & 2,836 & 0.005 & Sig \\
\hline Emotional Intelligence $\rightarrow$ Social Media $\rightarrow$ SME Performance & 3,174 & 0.002 & Sig \\
\hline Social intelligence $\rightarrow$ Social Media $\rightarrow$ SME performance & 2,623 & 0.008 & Sig \\
\hline Spiritual Intelligence $\rightarrow$ Social Media $\rightarrow$ UKM Performance & 3,134 & 0.002 & Sig \\
\hline Social Media $\rightarrow$ UKM Performance & 4,638 & 0,000 & Sig \\
\hline Social Media $\rightarrow$ Sales & 3,185 & 0.002 & Sig \\
\hline SME Performance $\rightarrow$ Sales & 5,213 & 0,000 & Sig \\
\hline
\end{tabular}

\subsection{Discussion}

\section{a. Entrepreneurial Intelligence Has A Positive And Significant Effect On Social Media}

The results of the first hypothesis show the relationship between the variables of entrepreneurial intelligence which includes financial, emotional, social and spiritual intelligence with the role of social media showing the path coefficient value of each element of entrepreneurial intelligence $<0.05$ and the value of T-Statistics $>$ T-Table (1.993). Thus, hypothesis 1 is accepted. This explains that the intelligence possessed by an entrepreneur has a positive effect on social media. An entrepreneur can maximize social media in supporting his business activities. 


\section{b. Entrepreneurial intelligence positively and significantly influences the performance of SMEs}

The results of the first hypothesis show that the relationship between the entrepreneurial intelligence variables which includes financial, emotional, social and spiritual intelligence with the role of social media shows a path coefficient value of $<0.05$ and the value of T-Statistics > T-Table (1.993). Thus, hypothesis 1 is accepted. This indicates that every element of entrepreneurial intelligence has a positive effect on the performance of SMEs. Therefore, the development of SMEs should be based on each of these elements. This research is in line with the research conductedTheda \& Sukartha (2018), Pratama \& Suhaeni (2017) and Misnawati \& Yusriadi (2018) which states that entrepreneurial intelligence affects the performance of SMEs.

\section{c. Entrepreneurial Intelligence through the Role of Social Media in a Positive and Significant Effect on the Performance of SMEs}

The results of testing the third hypothesis show that the relationship between the entrepreneurial intelligence variable through the role of social media on the performance of SMEs shows a path coefficient value of 0.008 with a T-Statistics value of 2.623. This value is greater than the T-Table (1.992). Thus, hypothesis 3 is accepted. This explains that the intelligence of an entrepreneur in utilizing the role of social media is proven to improve the performance of SMEs. In other words, social media as an intervening variable can have a positive impact on improving the performance of SMEs.

\section{d. Social Media Positively and Significantly Influences the Performance of SMEs}

The results of testing the fourth hypothesis show that the social media variable relationship with the performance of SMEs shows a path coefficient value of 0.000 with a T-Statistics value of 4.638. This value is greater than the T-Table (1.992).Thus, hypothesis 4 is accepted. This indicates that the use of social media provides performance benefits to SMEs which include customer service performance, sales, marketing and internal operations. Through social media, improvement in the performance of SMEs, both nonfinancial and financial, can be achieved. So that the optimization of the use of social media can be a competitive advantage for SMEs in this era of globalization. The results of this study are in line with the research conducted Purwantini \& Anisa (2018), Hendrawan (2019) and Daughter \& Ie (2020) which states that social media has a positive effect on the performance of SMEs.

\section{e. Social Media Positively And Significantly Affects Sales}

The results of testing the fifth hypothesis show that the social media variable relationship with sales shows a path coefficient value of 0.002 with a T-Statistics value of 3.185. This value is greater than the T-Table (1.992).Thus, hypothesis 5 is accepted. Entrepreneurs use social media as a marketing tool because through this tool they can build a very fast support network which is essential for business growth. Social media can help business owners work more efficiently, for example in the promotion section. Business owners are becoming more initiative in marketing with social media. The use of social media by SMEs can increase sales and expand the sales area. It is proven that SMEs that are able to adapt to technological developments such as social media will be superior in competition in the market. This research is in line with research Handaruwati (2017), Pradiani (2017), Misnawati \& Yusriadi (2018) and Setiawan et al. (2019) which states that social media has an effect on sales. 


\section{d. SME Performance Positively and Significantly Affects Sales}

The results of testing the sixth hypothesis show that the relationship between the performance of SMEs and sales shows a path coefficient of 0.000 with a T-Statistics value of 5.213. This value is greater than the T-Table (1.992). Thus, hypothesis 6 is accepted. Good SME performance can affect sales levels. Various efforts are made by entrepreneurs in business activities in order to achieve maximum performance and ensure maximum profit achievement. The results of this study are in line with the research conducted by Purwaningsih \& Kusuma (2015) Kore \& Septarini (2018), with research results that prove that the performance of SMEs can increase sales.

\section{Conclusion}

Based on the findings and discussion of the results described in the previous section, the conclusions that can be conveyed include: entrepreneurial intelligence consisting of financial intelligence, emotional intelligence, social intelligence and spiritual intelligence positively and significantly influences social media, entrepreneurial intelligence has a positive and significant effect. Significant on the performance of SMEs, entrepreneurial intelligence through the role of social media has a positive and significant effect on SME performance, social media has a positive and significant effect on SME performance and sales and SME performance has a positive and significant effect on sales.

The suggestions that can be given for the development of further research are that further research is expected to expand the research location, so that the test results regarding the performance of SMEs are more comprehensive and can expand previous research, and further research can increase the number of populations or samples used as observations in this study.

The limitation in this research is the use of a fairly small research sample. In addition, the scope of the research area is too narrow, that is, it is only limited. For this reason, further research can be developed in terms of the number of samples used and the wider coverage area

\section{References}

Balik, D., Joseph, CN, \& Silaya, MA (2018). The Influence of Spiritual Intelligence, Emotional Intelligence on Managerial Skills and Performance of SMEs (Studies on Christian Entrepreneurs in Ambon City). SOSOQ Journal, 6 (1), 27-33.

Handaruwati, I. (2017). The Influence of Social Media on Online Sales of Local Snack Products. Journal of Business and Management Bulletin, 3 (1), 41-52.

Kore, ELR, \& Septarini, DF (2018). Analysis of the Performance of Micro, Small and Medium Enterprises (MSMEs) (Case Study on SMEs in the Formal Small Industry Sector in Merauke Regency). Journal of Economic and Social Sciences, 9 (1), 22-37.

Ludin, I., Saleh, S., \& Amruloh, DAG (2018). The Influence of Intellectual Intelligence, Emotional Intelligence, and Spiritual Intelligence on the Performance of Muslim Entrepreneurs in Purwakarta Regency. Journal of Economics and Business, 8 (1), 8 18.

Mauludi, E. (2018). Exploratory and Explanatory Descriptive Research. Information Technology Communication Portal Computer Science, Information Systems, Research Methodology, Mathematics, Algorithms, and Computer Programming. https://www.elfanmauludi.tech/2018/09/pen Research-descriptif-eskploratoridan.html 
Misnawati, \& Yusriadi, Y. (2018). Management Effectiveness Based on Personal Cognitive Entrepreneurship Through the Use of Digital Infrastructure (Social Media). Journal of Management Partners, 2 (3), 138-145. https://doi.org/https://doi.org/10.52160/ejmm.v2i3.83

Pradiani, T. (2017). The Effect of the Digital Marketing System on the Increase in Sales Volume of the Home Industry Products Scientific Journal of Asian Business and Economics, 11 (2), 46-53.

Pratama, AY, \& Suhaeni, T. (2017). The Effect of Emotional Intelligence on Employee Performance. Journal of Research and Investment, 3 (2), 51-62.

Pranowo, A. S., Sutrisno, J., Sulastiono, P., \& Siregar, Z. M. E. (2020). The Entrepreneurial Competency, Innovation Capability, and Business Success: The Case of Footwear Industry in Indonesia. Quality - Access to Success, 21(178).

Purwaningsih, R., \& Kusuma, PD (2015). Analysis of the factors that affect the performance of Small and Medium Enterprises (UKM) with the Structural Equation Modeling Method (Case study of SMEs based on the Creative Industry in Semarang City). Proceedings of the Faculty of Engineering SNST ,. Proceedings of SNST, 1, 7-12.

Purwantini, AH, \& Anisa, F. (2018). Analysis of the Use of Social Commerce for MSMEs: Antecedents and Consumers. Scientific Journal of Accounting, 16 (1), 47-63. https://doi.org/10.30595/kompartemen.v16i1.2413

Putri, YD, \& Ie, M. (2020). The Influence of Entrepreneurship Orientation, Environment and Social Media on MSME Business Performance in Jakarta. Journal of Managerial and Entrepreneurship, I2 (4), 1106-1114.

Santoso, R., Candraningrat, \& Binawati, L. (2017). Elements of Entrepreneurial Intelligence to Improve the Performance of Small and Medium Industries (IKM) in Surabaya. Journal of Business and Management, 10 (1), 73-89. https://doi.org/https://journal.unesa.ac.id/index.php/bisma/index

Segati, A. (2018). The Effect of Perceptions of Halal Certification, Product Quality, and Price on Perceptions of Increased Sales. JEBI (Journal of Islamic Economics and Business), 3 (2), 159-169. https://doi.org/10.15548/jebi.v3i2.175

Setiawan, IMD, Sukanteri, NP, Suryana, IM, \& Suparyana, PK (2019). The Influence of Social Media-Based Promotion on the Production Sales of Ayu Tangkas Women Farmers Group (KWT) in Megati Village. Journal of Social Sciences and Humanities, 8 (2), 227-234.

Siregar, Z. M. E., Suryana, Ahman, E., \& Senen, S. H. (2019). Does knowledge management enhance innovation: A literature review. International Journal of Scientific and Technology Research, 8(9), 1991-1994.

Siregar, Z. M. E., Suryana, Ahman, E., \& Senen, S. H. (2020). Knowledge management, innovation, and firm performance: The case of Batik industry in Indonesia. Quality Access to Success, 21(179), 27-32.

Syamsuri, A. R., \& Siregar, Z. M. E. (2018). Analisis Pelatihan, Disiplin Kerja, Remunerasi, dan Motivasi Berprestasi dengan Kepuasan Kerja Sebagai Variabel Intervening terhadap Kinerja Karyawan. JSHP ( Jurnal Sosial Humaniora Dan Pendidikan), 2(2), 95. https://doi.org/10.32487/jshp.v2i2.470

Yuni Rukhayatun. (2018). Analysis of the Influence of Emotional Intelligence, Spiritual Intelligence, and Motivation on Employee Performance at PT. BPR Artha Huda Abadi Pati [Walisongo State Islamic University Semarang]. https://doi.org/10.1017/CBO9781107415324.004 